\title{
ZAKAT SEBAGAI INSTRUMEN FINANSIAL DALAM USAHA PEMULIHAN KONDISI EKONOMI DAN SOSIAL BUDAYA MENURUT PERSPEKTIF ISLAM
}

\author{
${ }^{1}$ Muharir, ${ }^{2}$ Mustikawati \\ ${ }^{1}$ Sekolah Tinggi Ekonomi dan Bisnis Syariah (STEBIS) Indo Global Mandiri \\ Email: muhariri@stebisigm.ac.id \\ ${ }^{2}$ Sekolah Tinggi Ekonomi dan Bisnis Syariah (STEBIS) Indo Global Mandiri \\ Email: mustikawati@stebisigm.ac.id
}

\begin{abstract}
Zakat merupakan instrumen khas dalam agama Islam. Sebagaimana eksistensi perintah zakat dalam al-Qur'an yang mayoritas beriringan dengan perintah menegakkan shalat. Di samping berdimensi ibadah mahdah yang bersifat vertical, zakat sangat kental dengan dimensi sosial yang terasa horizontal. Dimensi sosial itu tampak nyata bahwa zakat diwajibkan seorang muslim yang dikategorikan berkecukupan hartanya untuk didistribusikan kepada orang lain yang masuk kategori mustahiq zakat. Pada tahun 2013 jumlah layanan pada program RMB awalnya hanya berjumlah 2.968 warga binaan, pada awal tahun 2014 meningkat menjadi 9.374 warga binaan, dan tidak menutup kemungkinan pada tahun 2015 akan jauh lebih meningkat lagi
\end{abstract}

Kata Kunci : Zakat, Instrumen Finansial, Islam

\section{DASAR PEMIKIRAN}

Zakat merupakan instrumen khas dalam agama Islam. Sebagaimana eksistensi perintah zakat dalam al-Qur'an yang mayoritas beriringan dengan perintah menegakkan shalat. Di samping berdimensi ibadah mahdah yang bersifat vertical, zakat sangat kental dengan dimensi sosial yang terasa horizontal. Dimensi sosial itu tampak nyata bahwa zakat diwajibkan seorang muslim yang dikategorikan berkecukupan hartanya untuk didistribusikan kepada orang lain yang masuk kategori mustahiq zakat. Itulah sebab mengapa zakat dilabeli ibadah maliyah ijtima'iyyah yang memiliki posisi sangat penting, strategis, dan menentukan, baik dari sisi ajaran maupun dari sisi pembangunan kesejahteraan umat. Yang sekali lagi, di samping merupakan ibadah berdimensi mahdhah, zakat juga berdimensi sosial (Siti Tatmainul Qulub \& Ahmad Munif ,2003 : 2) 
Selain dimensi sosial, dalam zakat terdapat juga unsur kebudayaan karena zakat sendiri merupakan peraturan yang telah diatur dalam al-Qur'an dalam pelaksanaanya, sehingga menjadi tradisi dan membudaya di kalangan umat Islam. Zakat ditunaikan dalam kurun waktu yang telah ditentukan dan disepakati oleh jumhur para ulama yaitu telah mencapai haul dan telah mencapai nisabnya pada harta umat muslim yang akan dikeluarkan hartannya.

Zakat merupakan intrumen finansial yang dapat dimanfaatkan untuk menanggulangi masalah ekonomi, terutama pada kefakiran, kemiskinan. Pasalnya zakat di peruntukan kepada delapan asnap penerima zakat yang tercantum dalam al-Qur'an sebagai berikut:

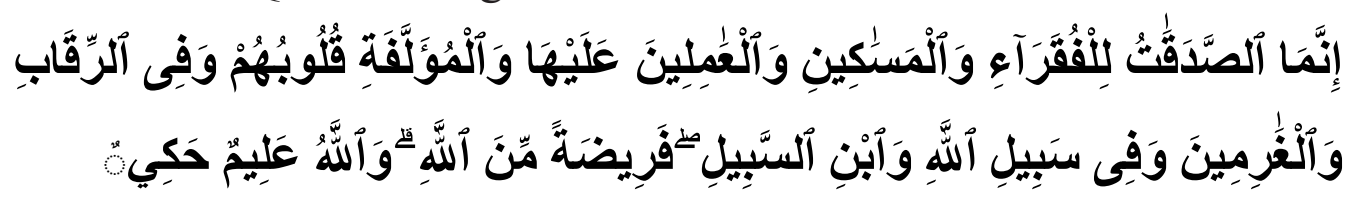

Artinya: "Sesungguhnya zakat-zakat itu, hanyalah untuk orang-orang fakir, orangorang miskin, pengurus-pengurus zakat, para muÂ'allaf yang dibujuk hatinya, untuk (memerdekakan) budak, orang-orang yang berhutang, untuk jalan Allah dan untuk mereka yuang sedang dalam perjalanan, sebagai suatu ketetapan yang diwajibkan Allah, dan Allah Maha Mengetahui lagi Maha Bijaksana."

Itulah dalil yang menerangkan siapa saja yang berhak menerima zakat, yaitu orang fakir, orang miskin, Amilin, Muallaf, Riqob, Ghorimin, Fii Sabilillah, dan Ibnu sabil. Salah satu dari delapan asnaf yang ditentukan al-Qur'an dan hadis adalah kategori fî sabîlillâh. Berbeda dengan tujuh asnaf lain yang jelas kedudukannya, fî sabîlillâh terasa tampak global dan belum jelas kepada siapa dan apa ia ditunjukkan.

Ini mungkin dikarenakan kata fî sabîlillâh seakan tidak (bisa) berdiri sendiri. Kata fî sabîlillâh yang secara literal bermakna di jalan Allah seperti membutuhkanpendamping. (https://pengertianzakatmu.blogspot.com/2015/03/daliltentang-zakat.html di akses tanggal 30 Oktober 2019 pukul 14: 05 WIB ) 
Konteks fi sabilillah sering di gaungkan sebagai pejuang agama allah atau biasa dikatakan menjadi orang orang yang benar-benar memperjuangakan agama allah. Memperingati hari maulid Nabi Muhamad s.a.w, di bulan sawal atau membuat tradisi memperingati hari asyuro atau peringatan 10 muharam, ini merupakan contoh pengembangan pola pikir umat Islam di Indonesia dalam merealisasikan konteks $f i$ sabilillah dalam zakat, bahwa dapat disimpukan zakat merupakan intrumen finansial yang dapat memulihkan kondisi ekonomi, sosial dan budaya.

Dari penjelansan diatas tulisan berikut ini akan mengkaji zakat sebagai instrumen finansial dalam usaha pemulihan kondisi ekonomi dan sosial budaya menurut perspektif Islam .

\section{PEMBAHASAN}

\section{Zakat Sebagai Intrumen Finansial}

Menurut Menurut Muhammad Nejatullah Siddiqi Di dalam zakat mengandung aspek moral, sosial, dan ekonomi. Dalam aspek moral, zakat mengikis habis ketamakan dan keserakahan kelompok orang kaya. Dalam aspek sosial, zakat bertindak sebagai alat khas yang diberikan Islam untuk menghapuskan kemiskinan dalam masyarakat dengan menyadarkan kelompok kaya akan tanggungjawab sosial yang mereka miliki. Sementara dalam aspek ekonomi, zakat mencegah penumpukan kekayaan dalam tangan segelintir orang, memungkinkan kekayaan utuk disebarkan sebelum sempat menjadi besar, dan sangat berbahaya di tangan para pemiliknya. Zakat merupakan sumbangan wajib kaum muslimin untuk perbendaharaan negara (Mubarak, 2014: 118-119, Huda, dkk, 2015: 10, Havis Aravik, 2017: 1 )

Dari pendapat diatas menurut Muhammad Nejatullah Siddiqi, yang dikutip oleh Havis Aravik dari Mubarok, Huda dkk, menyatakan “ bahwa Di dalam zakat mengandung aspek moral, sosial, dan ekonomi" Itu artinya zakat dapat memberikan efek perubahan yang sangat signifikan bagi kehidupan manusia baik secara emosional, moral dan etikanya. Zakat juga sebagai alat khas yang sewaktu waktu dapat digunakan sebagai pengurangan kesenjangan sosial antara sikaya dan simiskin, dan dalam aspek ekonomipun zakat dapat dimasukan sebagai mencegah adanya penumpukan kekayaan 
94

Muharir,Mustikawati Zakat Sebagai Instrumen Finansial Dalam Usaha Pemulihan.

pada diri seseorang sehingga dengan berzakat manusia akan merasakan bagaimana rasa tanggungjawabnya kepada sesame umat muslim yang memiliki rasa persaudaraan yang tinggi.

Dalam hal lain zakat disebut pula sebagai salah satu karakteristik ekonomi Islam mengenai harta yang tidak dimiliki dalam bentuk perekonomian lain, karena sistem perekonomian di luar Islam tidak mengenal tuntutan Allah kepada pemilik harta agar menyisihkan sebagian harta tertentu sebagai pembersih jiwa dari sifat kikir, dengki, dan dendam (Huda, dkk, 2015: 10). Maka dari itu, Islam menjadikan instrumen zakat untuk memastikan keseimbangan pendapatan di masyarakat. Hal ini mengingat tidak semua orang mampu bergelut dalam kancah ekonomi. Dengan kata lain, sudah menjadi sunatullah jika di dunia ini ada yang kaya dan miskin. Pengeluaran dari zakat adalah pengeluaran minimal untuk membuat distribusi pendapatan menjadi lebih merata (Rozalinda, 2014, .Marnisah, Aravik dan Zamzam, 2019).

Dari penjelasan kedua ini yang dinyatakan oleh Muhammad Nejatullah Siddiqi, “ Islam menjadikan instrumen zakat untuk memastikan keseimbangan pendapatan di masyarakat" ini artinya instrument zakat yang digaungkan sebagai intrumen yang paling tepat untuk mengatasi maslah ekonomi di masyarakat bukan hanya itu zakat juga bias menjadi intrumen finansial untuk penyeimbang kerukunan kehidupan bermasyarakat.

Menurut Havis Aravik dalam jurnalnya yang berjudul Esensi Zakat Sebagai Intrumen Finansial, menyatakan Zakat memainkan peranan penting dan signifikan dalam distribusi pendapatan dan kekayaan, dan berpengaruh nyata pada tingkah laku konsumsi. Zakat berpengaruh pula terhadap pilihan konsumen dalam hal mengalokasikan pendapatnya untuk tabungan atau investasi dan konsumsi. Pengaruhpengaruh baik dari zakat pada aspek sosial ekonomi memberikan dampak terciptanya keamanan masyarakat dan menghilangkan pertentangan kelas karena ketajamannya perbedaan pendapatan. Pelaksanaan zakat oleh negara akan menunjang terbentuknya keadaan ekonomi yang "growth with equality"; peningkatan produktifitas yang dibarengi dengan pemerataan pendapatan serta peningkatan lapangan pekerjaan bagi masyarakat. 
Menurutnya " growth with equality” yang memiliki arti peningkatan produktifitas yang dibarengi dengan pemerataan pendapatan serta peningkatan lapangan pekerjaan bagi masyarakat. Dari pendapat ini dapat disimpulkan bahwa peningkatan produktifitas yang dibarengi pemerataan akan berdampak juga kepada pengurangan kesenjangan sosial, jika hal ini dibudayakan pada idiologi dan pandangan hidup manusia secara nyata maka zakat akan berfungsi sebagaimana mestinya, kemudian pernyataan ini juga dususul dengan adanya pendapat yang dikemukakan oleh Abu Ubaidah Yusuf bin Mukhtar as Sidawi, yang menyatakan bahwa ada beberapa macam jenis zakat mal yang di abad modrn ini menjadi intrumen finansial yang paling real, sebut saja zakat profesi, zakat profesi berupa gaji yang diterima orang dalam setiap bulan gaji. Gaji berupa uang ini merupakan harta sehingga masuk dalam katagori zakat harta. Dikenakan zakat harta apabila gaji yang diperoleh telah memenuhi persyaratan sebagai berikut: (Ubaidah Yusuf bin Mukhtar as Sidawi, 2014: 183)

a. Mencapai nishab baik gaji murni atau dengan gabungan harta lainya.

b. Mencapai haul

Apabila telah terpenuhi syarat- syarat diatas maka gaji yang diperoleh wajib dizakati. Adapun bila gaji kurang dari nishab atau belum berlalu satu tahun, bahkan ia dibelanjakan sebelumnya, maka tidak wajib dizakati. Demikian para ulama kita menyatakan jumhurnya.

\section{Zakat Sebagai Untrumen Usaha Pemulihan Kondisi Ekonomi}

Pada penjelasan sebelumnya zakat merupakan intrumen yang masuk dalam katagori intrumen finansial yang bisa mengurangi beban ekonomi pada masyarakat, karena zakat memang diwajibkan kepada orang kaya yang memiliki kekayaan yang sudah mencapai nisabnya dan mengeluarkan zakat tersebut kepada orang yang berhak mendapatkan zakat ( Zakat Mal).

Adanya perbedaan harta, kekayaan, dan status sosial dalam kehidupan adalah sunatullah. Bahkan dengan adanya perbedaan status sosial itu manusia membutuhkan antara satu dengan lainnya. Zakat adalah salah satu instrumen yang paling efektif untuk menyatukan ummat manusia untuk saling membantu permasalahan kemiskinanan dalam kehidupan sosial masing-masing. Zakat merupakan ibadah yang memiliki posisi yang 
96 | Muharir,Mustikawati Zakat Sebagai Instrumen Finansial Dalam Usaha Pemulihan.

penting, strategis, dan menentukan bagi pembangunan kesejahteraan ummat. Ajaran zakat memberikan landasan bagi tumbuh dan berkembangnya kekuatan sosial-ekonomi ummat. Kandungan ajaran zakat ini mempunyai dimensi yang luas dan kompleks, bukan saja nilai ibadah, moral, dan spiritual, melainkan juga nilai-nilai ekonomi. ( Mukhamat Saini, 2011: 149)

"Ajaran zakat memberikan landasan bagi tumbuh dan berkembangnya kekuatan sosial-ekonomi ummat. Kandungan ajaran zakat ini mempunyai dimensi yang luas dan kompleks, bukan saja nilai ibadah, moral, dan spiritual, melainkan juga nilai-nilai ekonomi" dari pernyataan ini artinya zakat dapat dipergunakan untuk usaha pemulihan kondisi ekonomi yang mulai melemah, zakat merupakan salah satu rangkaian ibadah maliah yang harus ditunaikan oleh umat Islam karena zakat termasuk kedalam rukun Islam yang ke empat, artinya zakat ( Zakat Mal ) dapat dipergunakan untuk usaha pemulihan ekonomi umat, terutama pada masalah pengentasan kemiskinan.

Dalam tulisan lain disebutkan bahwa dalam era kontemporer sekarang ini zakat bisa menjadi nilai produktif, Lembaga pengelola zakat harus mampu memaksimalkan seluruh potensi zakat yang ada dari masyarakat, dengan melakukan pengelolaan zakat yang sesuai dengan syari'ah dan Undang-Undang No. 23 Tahun 2011 tentang Zakat. Lembaga pengelola zakat harus mampu menumbuhkan kesadaran masyarakat melalui pendekatan yang persuasif melalui sosialisasi ajaran zakat dan infaq. Lembaga pengelola zakat berhak pula mengelola zakat untuk usaha produktif dan mendistribusikan zakat pada target mustahik yang tepat, semua itu semata-mata untuk pemerataan, keadilan dan pengentasan kemiskinan. (Mukhamat Saini, 2011: 150 )

Di Indonesia, zakat diatur secara khusus pengelolaanya pada Undang Undang Nomor 23 Tahun 2011 tentang Pengelolaan Zakat. Menurut Undang-Undang tersebut terdapat dua badan yang berhak mengelola zakat antara lain, yang pertama Badan Amil Zakat yang dikelola pemerintah dan kedua Lembaga Amil Zakat yang dikelola masyarakat. Dalam konteks kehidupan bernegara, dua lembaga pengelola zakat tersebut sangatlah berperan penting dalam melaksanakan pengelolaan dana zakat, keduanya merupakan lembaga penting yang akan menentukan keberhasilan dari pengeololaan potensi ekonomi ( Mukhamat Saini, 2011: 150 ) 
Badan Amil Zakat Nasional (BAZNAS) adalah sebuah lembaga yang dibentuk oleh pemerintah berdasarkan UU No. 38 Tahun 1999 dan UU No. 23 Tahun 2011. Kemudian, Peraturan Pemerintah Nomor 14 Tahun 2014 tentang Pelaksanaan UU Pengelolaan Zakat. Tetapi sayang, UU ini belum melahirkan efek jera bagi orang yang tidak membayar zakat. Di tingkat Kabupaten/Kota dengan SK Bupati/Walikota atas usul Kepala Kantor Kementerian Agama Kabupaten/Kota disebut dengan Badan Amil Zakat Daerah (BAZDA). Sedangkan di kecamatan dengan SK Camat atas usul Kepala KUA. Pada tingkat Desa/Dinas/Badan/Kantor/Instansi lain dapat dibentuk Unit Pengumpul Zakat (UPZ) oleh BAZNAS. Prinsip zakat dalam tatanan sosial ekonomi mempunyai tujuan untuk memberikan pihak tertentu yang membutuhkan untuk menghimpun dirinya selama satu tahun ke depan dan bahkan diharapkan sepanjang hidupnya. Dalam konteks ini, zakat didistribusikan untuk dapat mengembangkan ekonomi baik melalui keterampilan yang menghasilkan maupun dalam bidang perdagangan. (Mukhamat Saini, 2011: 151).

Dari dua sumber kutipan diatas zakat secara peraturan undang-undang di Negara Indonesia telah ditentukan, lebih daripada itu pengumpulan zakat mulai diarahkan untuk peningkatan mutu kualitas taraf hidup manusia. “ Prinsip zakat dalam tatanan sosial ekonomi mempunyai tujuan untuk memberikan pihak tertentu yang membutuhkan untuk menghimpun dirinya selama satu tahun ke depan dan bahkan diharapkan sepanjang hidupnya" pada kalimat ini terlihat jelas bahwa zakat juga memiliki prinsip dalam tatanan sosial ekonomi membawa fungsi zakat bukan yang bersifat satu kali pakai, namun bisa menjadi sepanjang hidup.

Selain itu juga zakat dalam kata lain adalah pemberdayaan dari sumber pendapatan yang diperoleh oleh individu yang di keluarkan oelh individu tersebut untuk kepentingan umat menurut Saepudin Elman konsep pemberdayaan zakat adalah sebagai berikut: Pemberdayaan masyarakat atau community development (Comdev), memiliki tujuan utama yaitu memberdayakan individu-individu dan kelompok-kelompok orang melalui penguatan kapasitas (termasuk kesadaran, pengetahuan dan keterampilanketerampilan. yang diperlukan untuk mengubah kualitas kehidupan komunitas mereka. Kapasitas tersebut seringkali berkaitan dengan penguatan aspek ekonomi dan politik melalui pembentukan kelompok-kelompok sosial besar yang bekerja berdasarkan 
981

Muharir,Mustikawati Zakat Sebagai Instrumen Finansial Dalam Usaha Pemulihan.

agenda bersama. Tujuan yang ingin dicapai dari pemberdayaan menurut Sulistriyani adalah untuk membentuk individu dan masyarakat menjadi mandiri. Kemandirian tersebut meliputi, kemandirian berfikir, kemandirian ekonomi, bertindak dan mengendalikan apa yang mereka lakukan tersebut. Untuk mencapai kemandirian masyarakat diperlukan sebuah proses, melalui sebuah proses belajar maka secara bertahap masyarakat akan memperoleh kemampuan atau daya dari waktu ke waktu. Berikut ini tujuan pemberdayaan menurut Tjokowinoto yang dirumuskan ke dalam tiga bidang yaitu ekonomi, politik, dan sosial budaya. Kegiatan pemberdayaan harus dilaksanakan secara menyeluruh menyakup segala aspek kehidupan masyarakat untuk membebaskan kelompok masyarakat dari dominasi kekuasan yang meliputi bidang ekonomi, politik, dan sosial budaya. (Saepudin Elman, 2015: 41).

Konsep pemberdayaan dibidang ekonomi adalah usaha menjadikan ekonomi yang kuat, besar, mandiri, dan berdaya saing yang amat tinggi dalam mekanisme pasar yang besar dimana terdapat sebuah proses penguatan golongan ekonomi lemah. Sedangkan pemberdayaan dibidang politik merupakan penguatan rakyat kecil dalam proses pengambilan keputusan yang menyangkut kehidupan berbangsa dan bernegara khususnya atau kehidupan mereka sendiri. Konsep pemberdayaan dibidang social budaya merupakan upaya penguatan rakyat kecil melalui peningkatan, penguatan, dan penegakan nilai-nilai gagasan, serta mendorong terwujudnya organisasi sosial yang mampu memberikan kontrol terhadap perlakuan-perlakuan politik dan ekonomi yang jauh dari moralitas.

Adapun tujuan Pemberdayaan menurut Undang-Undang No. 20 tahun 2008 tentang Usaha Mikro Kecil dan Menengah pasal 5 adalah: ( Saepudin Elman, 2015: 43) mewujudkan struktur perekonomian nasional yang seimbang, berkembang,dan berkeadilan;enumbuhkan dan mengembangkan kemampuan Usaha Mikro,Kecil, dan Menengah menjadi usaha yang tangguh dan mandiri; dan Meningkatkan peran Usaha Mikro, Kecil, dan Menengah dalam pembangunan daerah, penciptaan lapangan kerja, pemerataan pendapatan, pertumbuhan ekonomi, dan pengentasan rakyat dari kemiskinan. 


\section{Dampak Penyaluran Dana Zakat Melalui Program Pemberdayaan Ekonomi Terhadap Peningkatan Ekonomi Masyarakat}

BAZNAS merupakan lembaga yang bagus dalam menjalankan kegiatan penyaluran dana zakat serta mempunyai manajemen yang bagus. Begitu banyak program yang dimunculkan oleh BAZNAS tercover dengan baik, tentunya dengan dirancangnya setiap program-program tersebut memberikan harapan dan memberikan dampak yang positif bagi mustahik, karena kembali kepada tujuan program pemberdayaan ekonomi yang dilakukan oleh BAZNAS itu sendiri, memberdayakan potensi diri masyarakat, serta mengatasi problem kemiskinan dengan pemberdayaan ekonomi. Pemberdayaan Ekonomi yang dilakukan oleh BAZNAS memang sangatlah luas ruang lingkupnya, karena lembaga ini telah melakukan programnya dibeberapa wilayah yang ada di Indonesia. ( Saepudin Elman, 2015: 74 )

Dengan dijalankannya strategi penyaluran yang bagus, maka program- program yang dijalankanpun berjalan dengan baik. Karena suatu organisasi tanpa adanya strategi, maka program pemberdayaan ekonomi masyarakat tidak akan berjalan semaksimal mungkin. Strategi yang dilakukan dalam suatu organisasi sangat mempengaruhi jumlah penyaluran dana zakat. ( Saepudin Elman, 2015: 74).

Model strategi penyaluran dana zakat yang dilakukan BAZNAS adalah dengan menggunakan dua metode saja yaitu penyaluran yang secara langsung dan penyaluran yang tidak langsung. Dari dua model strategi ini BAZNAS telah membuktikan peningkatan jumlah layanan program pemberdayaan Jumlah Layanan Program Pemberdayaan Ekonomi program Rumah Makmur Baznas (RMB) ini dari tahun ke tahun semakin meningkat. Pada tahun 2013 jumlah layanan pada program RMB awalnya hanya berjumlah 2.968 warga binaan, pada awal tahun 2014 meningkat menjadi 9.374 warga binaan, dan tidak menutup kemungkinan pada tahun 2015 akan jauh lebih meningkat lagi. ( Saepudin Elman, 2015: 76). 


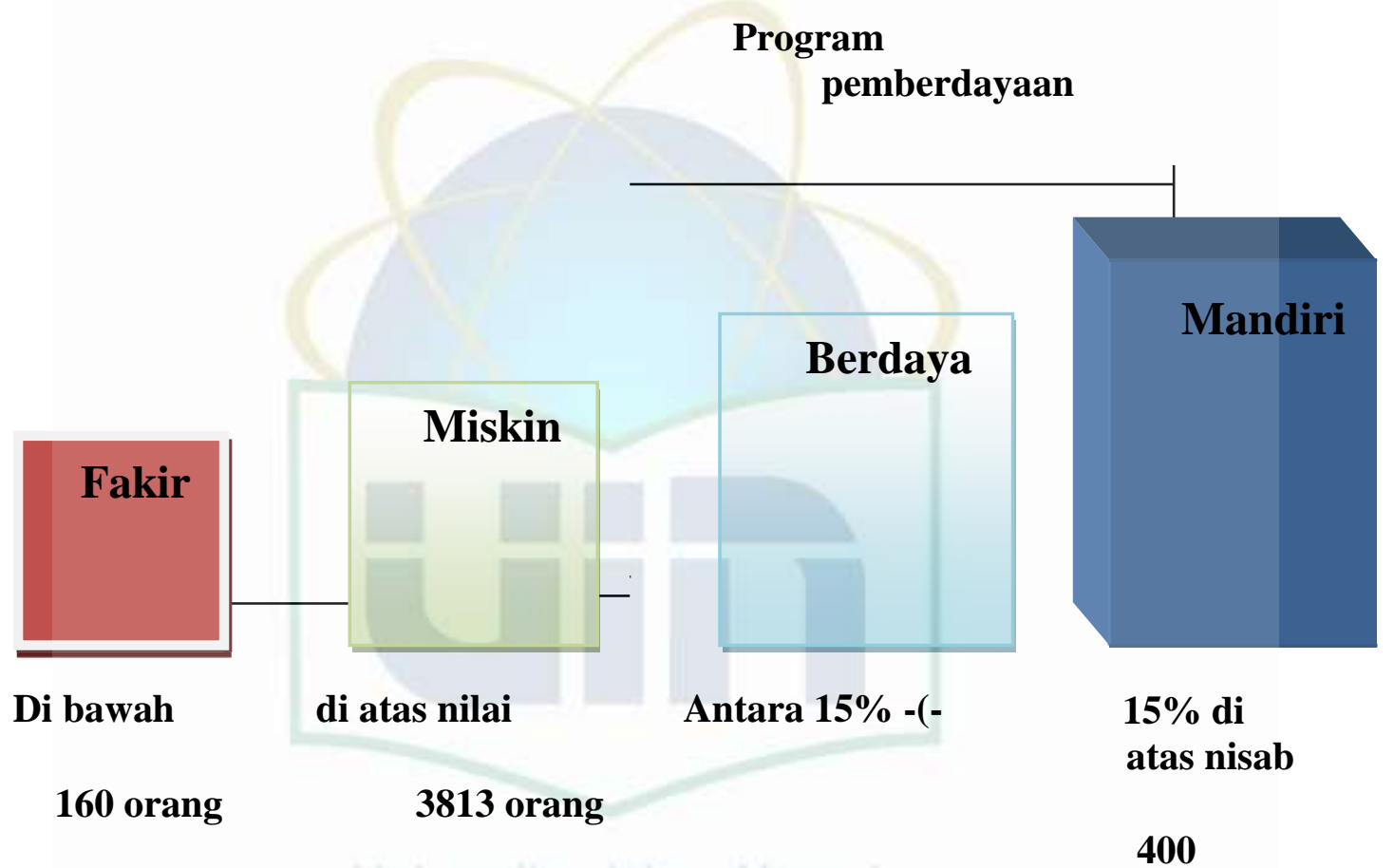

Sumber : Rumah Makmur

\section{KESIMPULAN}

Berdasarkan uraian-uraian yang telah dipaparkan sebelumnya maka dapat diambil kesimpulan bahwa mekanisme yang digunakan oleh BAZNAS dalam menyalurkan dana zakat, menggunakan dua strategi dalam penyaluran yaitu:

1. Penyaluran dana zakat yang dilakukan secara langung yang bersifat konsumtif. Dana zakat ini disalurkan langsung kepada mustahik dengan cara membuka layanan konter mustahik, layanan kesehatan Cuma-Cuma bagi mustahik, layanan beasiswa bagi mustahik, pemberian modal untuk usaha bagi mustahik.

2. Penyaluran dana zakat yang dilakukan secara tidak langsung yang bersifat produktif. Dana zakat ini tidak disalurkan secara langsung kepada mustahik melainkan BAZNAS melakukan pemberdayaan kepada mustahik berupa, pelatihan kewirausahaan untuk mustahik, pemberdayaan nelayan bagi mustahik, pemberdayaan perempuan, dan pemberdayaan bagi petani. 
Ekonomica Sharia Volume 5 Nomor 2 Edisi Februari $2020 \mid 101$

3. Dampak penyaluran dana zakat melalui program pemberdayaan ekonomi bagi masyarakat adalah. Mustahik yang sudah mengikuti program pemberdayaan yang dilakukan oleh BAZNAS mampu meningkatkan kebutahan ekonomi bagi keluarganya. Pada tahun 2014 dari jumlah 9.374 mustahik yang dipemberdayakan oleh BAZNAS mengalami perkembangan sebesar 10\% dari jumlah tersebut.

\section{DAFTAR PUSTAKA}

Tatmainul Qulub Siti \& Ahmad Munif Pemaknaan Fî sabîlillâh sebagai Mustahik Zakat menurut Ulama Kontemporer, 2015 UIN Walisongo Semarang

Ali Nurdin Mhd. Ali. Zakat Sebagai Instrumen dalam Kebijakan Fiskal.Jakarta : PT. Raja Grafindo Persada 2006.

Amsari,Fuad. Islam kaafah tantangan dan aplikasinya , Jakarta ;Gip, 1995.

Aravik, Havis, Ekonomi Islam; Teori, Konsep dan Aplikasi Serta Pandangan Pemikir Ekonomi Islam dari Abu Ubaid Sampai Al-Maududi, Malang: Empat Dua, 2016.

Aravik, Havis. Sejarah Pemikiran Ekonomi Islam Kontemporer, Jakarta: Kencana, 2017.

Aravik, Havis. "Esensi Zakat sebagai Instrumen Finansial Islami dalam Pandangan Muhammad Nejatullah Siddiqi." Ekonomica Sharia 2, no. 2 (2017): 101-112.

Bariyah, Nurul Oneng. Total Quality Management Zakat prinsip dan praktek Pemberdayaan Ekonomi, Wahana Kardofa FAI UMJ: 2012.

Bariadi Lili, dkk. Zakat dan Wirausaha, Ciputat: CED, 2005.

Badan Pembinaan Hukum Nasional Departemen Kehakiman,Naskah Akademis Peraturan Per Undang-Undangan tentang Perlindungan Usaha Kecil, 1991.

Marnisah, Luis, Havis Aravik, and Fakhry Zamzam. "Dari Kisah Hayy Bin Yaqzhan Sampai Moralitas Ekonomi; Pemikiran Ekonomi Ibn Thufail." SALAM: Jurnal Sosial dan Budaya Syar-i 6, no. 4 (2019): 343-354.

(https://pengertianzakatmu.blogspot.com/2015/03/dalil-tentang-zakat.html di akses tanggal 30 Oktober 2019 pukul 14: 05 WIB ) 